\title{
PENERAPAN MODEL PEMBELAJARAN BERBASIS MASALAH UNTUK MENINGKATKAN KEMANDIRIAN BELAJAR SISWA
}

\author{
Yeni Rahmawati ${ }^{1}$ \\ Dosen STKIP Al-Amin Dompu \\ Email: yenisangiangapi11@gmail.com
}

\begin{abstract}
As one institution that provides formal education, schools have a very important role in realizing the goals of national education through the process of teaching and learning. The education has a function, (Law No.20 of 2003 article 3) is as follows: National Education functions to develop the ability and shape the character and civilization of the nation that is useful in order to educate the nation's life, aiming for the potential of students to become learners who believe, fear God, be noble, healthy knowledgeable, creative, independent and become a democratic and responsible citizen. The methods used in Data Collection are Interview Method, Observation Method, Documentation Method and Method of Questionnaire. Based on the results of the questionnaire score of students learning independence class IX on the first cycle has been tiggi $67.5 \%$ and $32.5 \%$. Students who scored $44-62$ as many as 13 people and students who scored 63-81 as many as 27 people so that classically obtained an average score of 65.62. In cycle II obtained data that there are $5 \%$ of students who already have a very high learning independence, $72.5 \%$ students with high independence and $22.5 \%$ of students have less high learning independence. Students who scored 44-62 as many as 9 people, students who scored 63-81 as many as 29 people, and students who scored $82-100$ as many as 2orang so obtained a score of 67.45 .
\end{abstract}

Keyword: Problem-based learning and learning independence

\begin{abstract}
Abstrak: Sebagai salah satu lembaga yang menyelenggarakan pendidikan secara formal, sekolah memiliki peranan yang sangat penting dalam mewujudkan tujuan pendidikan nasional melalui proses belajar mengajar. Pendidikan tersebut mempunyai fungsi, (UU No.20 tahun 2003 pasal 3) adalah sebagai berikut: Pendidikan Nasional berfungsi mengembangkan kemampuan dan membentuk watak serta peradaban bangsa yang bermanfaat dalam rangka mencerdaskan kehidupan bangsa, bertujuan untuk perkembangann potensi siswa didik agar menjadi peserta didik yang beriman, bertakwa pada Tuhan, berakhlak mulia, sehat berilmu, kreatif, mandiri dan menjadi warga yang demokratis dan bertanggung jawab. Metode yang di guanakan dalam
\end{abstract}

\footnotetext{
${ }^{1}$ Dosen Sekolah Tinggi Agama Islam Al-Amin Dompu Provinsi Nusa Tenggara Barat
} 
Pengumpulan Data adalah Metode Wawancara, Metode Observasi, Metode Dokumentasi dan Metode Angket. Berdasarkan hasil skor angket kemandirian belajar siswa kelas IX pada siklus I sudah tiggi yaitu $67,5 \%$ dan $32,5 \%$. Siswa yang memperoleh skor 44-62 sebanyak 13 orang dan siswa yang memperoleh skor 63-81 sebanyak 27 orang sehingga secara klasikal diperoleh rata-rata skor 65,62. Pada siklus II diperoleh data bahwa ada $5 \%$ siswa yang sudah memiliki kemandirian belajar sangat tinggi, 72,5\% siswa dengan kemandirian tinggi dan sebesar 22,5\% siswa memiliki kemandirian belajar kurang tinggi. Siswa yang memperoleh skor 44-62 sebanyak 9 orang, siswa yang memperoleh skor 63-81 sebanyak 29 orang, dan siswa yang memperoleh skor 82-100 sebanyak 2orang sehingga diperoleh rerata skor 67,45.

Kata Kunci: Pembelajaran berbasis masalah dan kemandirian belajar

\section{Pendahuluan}

Berbicara masalah prestasi belajar sangatlah luas, pihak pengelola pendidikan telah melakukan berbagai usaha untuk memperoleh kualitas dan kuantitas pendidikan dalam rangka meningkatkan prestasi belajar siswa yang selanjutnya terwujudlah perubahan-perubahan dalam pengorganisasian kelas, penggunaan metode mengajar, strategi belajar mengajar.

Prestasi belajar pada hakekatnya merupakan pencerminan dari usaha belajar. Semakin baik usaha belajar semakin baik pula prestasi yang dicapai. Pada dasarnya keberhasilan belajar ditentukan oleh dua faktor yang berasal dari dalam diri siswa dan dari luar siswa antara lain komunikasi guru dengan siswa, dan bimbingan orang tua.

Madrasah Aliyah Assa'adah Labuapi Kabupaten Lombok Barat Provinsi Nusa Tenggara Barat merupakan salah satu lembaga pendidikan swasta yang selalu membantu siswanya untuk mencapai prestasi belajar yang maksimal dan berbudaya imtak. Hal ini sesuai dengan salah satu misi dari Madrasah Aliyah Assa'adah Labuapi Lombok Barat yaitu Berprestasi, Terampil dan Berbudaya Imtaq, walaupun masih terdapat kekurangan pada proses belajar mengajar yang terjadi di Madrasah Aliyah Assa’adah Labuapi Lombok Barat Tahun Pelajaran 2016-2017.

Sering terjadi masalah dalam proses belajar mengajar yang di sebabkan adanya perbedaan persepsi antara siswa dengan guru dari materi yang diajarkan oleh guru. Dari 265 siswa yang ada di kelas XI Madrasah Aliyah Assa'adah Labuapi Kabupaten 
Lombok Barat Provinsi Nusa Tenggara Barat yang dapat dikatagori baik komunikasi siswa dengan Guru 7,5\% sedangkan 2,5\% belum dikategori dapat berkomunikasi dengan baik antara siswa dengan guru.

Komunikasi adalah suatu proses penyampaian informasi (pesan, ide, gagasan) dari satu pihak kepada pihak lain agar terjadi saling mempengaruhi diantara keduanya. Komunikasi yang dilakukan oleh seorang guru dan siswa merupakan hal yang harus dibina dengan baik karena hal tersebut merupakan suatu hal yang penting dalam menentukan keberhasilan belajar siswa. Manfaat dari komunikasi dalam belajar adalah diketahui permasalahan yang dihadapi siswanya dalam belajar dan guru dapat memecahkannya. Komunikasi yang positif antara guru dengan siswa akan menghasilkan individu yang senantiasa mempunyai semangat yang positif dalam belajar.

Bimbingan adalah suatu proses pemberian bantuan yang terus menerus dan sistematis kepada individu dalam memecahkan masalah yang dihadapinya sesuai dengan potensi atau kemampuannya dalam mencapai penyesuaian dengan lingkungannya, baik lingkungan keluarga, sekolah maupun masyarakat. Adanya bimbingan orang tua di rumah akan membantu menumbuhkan semangat belajar siswa. Adanya bimbingan orang tua maka akan dapat membantu mengarahkan anaknya dalam memecahkan masalah, mengarahkan waktu belajar dengan baik, membantu dalam menyediakan fasilitas belajar anak, dan lain sebagainya.

Prestasi belajar merupakan gambaran dari keberhasilan suatu proses belajar mengajar secara keseluruhan. Dalam hal ini perlu adanya sekedar introspeksi terhadap bimbingan kepada anak. Tidak semua anak yang telah menginjak kedewasaan secara biologis, dengan sendirinya dapat mandiri secara sosial, apabila orang tua begitu saja melepas anak untuk berdiri sendiri, maka kemungkinan besar ia akan kehilangan pegangan karena memang perkembangan jiwanya tidak diarahkan ke tujuan yang baik.

Bimbingan orang tua sangat dibutuhkan untuk membantu pencapaian prestasi secara maksimal. Hal ini dikarenakan orang tua yang mengetahui kebutuhan anaknya akan memberi pengawasan belajar anak, kebutuhan fasilitas penunjang belajar, memberi motivasi anak dalam belajar. Selain itu orang tua harus berusaha 
menciptakan suasana belajar yang baik di lingkungan keluarga, sebab lingkungan keluarga sangat berpengaruh besar terhadap semangat belajar anak di rumah.

\section{Tujuan Penelitian}

Berdasarkan rumusan masalah tersebut maka tujuan yang ingin dicapai dalam penelitian ini adalah:

1. Untuk mengetahui bagaimana komunikasi guru dengan siswa dalam pembelajaran IPS terpadu Kelas XI Madrasah Aliyah Assa'adah Labuapi Lombok Tahun Pelajaran 2016-2017.

2. Untuk mengetahui bagaimana komunikasi guru dengan siswa dengan bimbingan orang tua dalam pembelajaran IPS terpadu siswa kelas XI MA. Assa'adah Labuapi Lombok Barat Tahun Pelajaran 20162017.

3. Untuk mengetahui bagaimana prestasi belajar IPS terpadu pada siswa kelas XI MA. Assa'adah Labuapi Lombok Barat Tahun Pelajaran 2016-2017.

4. Untuk mengetahui adakah pengaruh komunikasi guru dengan siswa dan bimbingan orang tua terhadap prestasi belajar IPS terpadu pada siswa kelas XI MA. Assa'adah Labuapi Lombok Barat Tahun Pelajaran 2016-2017.

\section{Tinjauan Umum Komunikasi}

\section{Pengertian Komunikasi}

Kata atau istilah "komunikasi" (Bahasa Inggris "communication") berasal dari Bahasa Latin "communicatus" yang berarti "berbagi" atau "menjadi milik bersama". Dengan demikian, kata komunikasi menurut kamus bahasa mengacu pada suatu upaya yang bertujuan untuk mencapai kebersamaan. Menurut Webster New Collogiate Dictionary dijelaskan bahwa komunikasi adalah suatu proses pertukaran informasi di antara individu melalui sistem lambang-lambang, tanda-tanda atau tingkah laku. Berikut ini adalah bebarapa definsi tentang ilmu komunikasi yang dikemukakan oleh para ahli sebagai berikut: Hovland, Janis \& Kelley komunikasi adalah suatu proses melalui mana seseorang (komunikator) menyampaikan stimulus (biasanya dalam bentuk kata-kata) dengan tujuan mengubah atau membentuk perilaku orang-orang lainnya (khalayak.Berelson \& Steiner Komunikasi adalah suatu proses penyampaian 
informasi, gagasan, emosi, keahlian dan lain-lain melalui penggunaan simbol-simbol seperti kata-kata, gambar, angka-angka dan lain-lain.

Harold Lasswell Komunikasi pada dasarnya merupakan suatu proses yang menjelaskan "siapa" "mengatakan "apa" "dengan saluran apa", "kepada siapa" dan "dengan akibat apa" atau "hasil apa", (who says what in which channel to whom and with what effect). Barnlund komunikasi timbul didorong oleh kebutuhan-kebutuhan untuk mengurangi rasa ketidakpastian, bertindak secara efektif, mempertahankan atau memperkuat ego. Weaver komunikasi adalah seluruh prosedur melalui mana pikiran seseorang dapat mempengaruhi pikiran orang lainnya. Gode yang dimiliki oleh seseorang (monopoli seseorang) menjadi dimiliki oleh dua orang atau lebih.

Dari berbagai definisi tentang ilmu komunikasi tersebut di atas terlihat bahwa para ahli memberikan definisinya sesuai dengan sudut pandangnya dalam melihat komunikasi. Masing-masing memberikan penekanan arti, ruang lingkup, dan konteks yang berbeda. Hal ini menunjukkan bahwa, ilmu komunikasi sebagai bagian dari ilmu sosial adalah suatu ilmu yang bersifat multi-disipliner. Definisi Hovland Cs, memberikan penekanan bahwa tujuan komunikasi adalah mengubah atau membentuk perilaku. Definisi Berelson dan Steiner, menekankan bahwa komunikasi adalah proses penyampaian, yaitu penyampaian informasi, gagasan, emosi, keahlian, dan lain-lain. Definisi Lasswell, secara eksplisit dan kronologis menjelaskan tentang lima komponen yang terlibat dalam komunikasi, yaitu: siapa (pelaku komunikasi pertama yang mempunyai inisiatif atau sumber mengatakan apa (isi informasi yang disampaikan), kepada siapa (pelaku komunikasi lainnya yang dijadikan sasaran penerima), melalui saluran apa (alat/saluran penyampaian informasi) dan dengan akibat/hasil apa (hasil yang terjadi pada diri penerima).

Definisi Lasswell ini juga menunjukkan bahwa komunikasi itu adalah suatu upaya yang disengaja serta mempunyai tujuan. Definisi Gode memberi penekanan pada proses penularanpemilikan, yaitu dari yang semula (sebelum komunikasi) hanya dimiliki oleh satu orang kemudian setelah komunikasi menjadi dimiliki oleh dua orang atau lebih. Definisi Barnlund menekankan pada tujuan komunikasi, yaitu untuk mengurangi ketidakpastian, sebagai dasar bertindak efektif dan untuk mempertahankan atau memperkuat ego.

\section{Pengertian Komunikasi Guru dengan Siswa}


Komunikasi adalah suatu proses penyampaian informasi (pesan, ide, gagasan) dari satu pihak kepada pihak lain agar terjadi saling mempengaruhi diantara keduanya. Pada umumnya, komunikasi dilakukan dengan menggunakan kata-kata (lisan) yang dapat dimengerti oleh kedua belah pihak. Adapun komunikasi antara guru dengan siswa adalah penyampaian materi pelajaran yang dilakukan guru kepada siswa dalam proses belajar mengajar di dalam kelas.

\section{Pola Komunikasi}

Ada tiga pola komunikasi yang dapat digunakan untuk mengembangkan intraksi dinamis antara guru dengan siswa.

a. Komunikasi sebagai aksi atau komunikasi satu arah

Dalam komunikasi ini guru berperan sebagai pemberi aksi dan siswa sebagai penerima aksi. Guru aktif dan siswa pasif. Ceramah pada dasarnya adalah komunikasi satu arah, atau komunikasi sebagai aksi.Komunikasi jenis ini kurang banyak menghidupkan kegiatan siswa belajar.

b. Komunukasi sebagai interaksi atau komunikasi dua arah

Pada komunikasi ini guru dan siswa dapat berperan sama yaitu pemberi aksi dan penerima aksi. Di sini sudah terlihat hubungan dua arah, tetapi terbats antara guru dan pelajar secara indivudual. Antara pelajar dan pelajar tidak ada hubungan. Pelajar tidak dapat berdiskusi dangan teman atau bertanya sesama temannya. Keduanya dapat saling memberi dan menerima. Komunikasi ini lebih baik dari pada yang pertama,sebab kegiatan guru dan kegiatan siswa relatif sama.

c. Komunikasi banyak arah atau komunikasi sebagai transaksi

Komunikasi ini tidak hanya melibatkan interaksi yang dinamis antara guru dengan siswa tetapi juga melibatkan interaksi yang dinamis antara siswa yang satu dengan yang lainnya. Proses belajar mengajar dengan pola komunikasi ini mengarah kepada proses pengajaran yang mengembangkan kegiatan siswa yang optimal, sehingga menumbuhkan siswa belajar aktif. Diskusi dan simulasi merupakan strategi yang dapat mengembangkan komunikasi ini.

Dalam kegiatan mengajar, siswa memerlukan sesuatu yang memungkinkan dia berkomunikasi secara baik dengan guru, teman, maupun dengan ligkungannya. Oleh karena itu dalam proses belajar mengajar terdapat dua hal yang ikut menentukan keberhasilannya yaitu pengaturan proses belajar mengajar dan 
pengajaran itu sendiri yang keduanya mempunyai ketergantungan untuk menciptakan situasi komunikasi yang baik yang memungkinkan siswa untuk belajar.

\section{Faktor-Faktor Yang Mempengaruhi Komunikasi}

Ada beberapa faktor yang harus dipertimbangkan dalam menentukan komunikasi dalam proses pengajaran. Adapun faktor tersebut adalah tujuan yang akan di capai adalah: sifat bahan pelajaran yang kurang sempurna, sumber belajar yang tersedia belum maksimal, karakteristik kelas belum memadai dan kemampuan guru itu sendiri dalam menyampaikam materi masih kurang di mengerti oleh sebagian siswa sehingga output dari guru belum sepenuhnya bisa di input oleh siswa. Jadi guru berupaya membuat situasi dan kondisi se baik mungkin demi tercapainya belajar yang kondusif serta guru berusaha membuat siswa dapat berkomuniasi dengan gurunya dengan lancar, baik dan tidak canggung, dengan demikian proses belajar mengajar yang diinginkan oleh guru dalam meningkatkan prestasi belajar siswa dapat meningkat secara signifikan.

\section{Tinjauan Umum Tentang Bimbingan Orang Tua}

\section{Pengertian Bimbingan}

Bimbingan adalah suatu proses pemberian bantuan yang terus menerus dan sistematis kepada individu dalam memecahkan masalah yang dihadapinya sesuai dengan potensi atau kemampuannya dalam mencapai penyesuaian dengan lingkungannya, baik lingkungan keluarga, sekolah maupun masyarakat.

Secara umum bimbingan dapat diartikan sebagai suatu bantuan. Namun untuk sampai kepada pengertian yang sebenarnya kita harus ingat bahwa tidak setiap bantuan dapat diartikan bimbingan. Bimbingan adalah terjemahan dari bahasa Inggris yaitu: guidance. Kata guidance berasal dari kata kerja to guidance artinya menunjukkan, membimbing, menuntun orang ke jalan yang benar. Jadi kata guidance berarti pemberian petunjuk, pemberian bimbingan pada orang lain yang membutuhkan.

\section{Bimbingan Orang Tua}

Kegiatan belajar diperlukan adanya bimbingan dari orang tua atau dan orang lain agar semangat dalam belajarnya. keluarga sebagai tempat pertama pertumbuhan dan perkembangan sangat menentukan peranannya. Orang tua merupakan orang pertama dan utama yang mampu, serta berhak menolong keturunannya dan mendidik anaknya. Orang tua peranannya dalam keluarga dan dapat menciptakan ikatan 
emosianal dengan anaknya, menciptakan suasana aman dirumah sehingga orang tua/rumah merupakan tempat anak untuk kembali, menjadi contoh/ model bagi anaknya, memberikan disiplin dan memperbaiki tingkah laku anak, menciptakan jaringan komunikasi diantara anggota keluarga.

Pengawasan dan bimbingan orang tua di rumah mutlak diperlukan karena adanya bimbingan, orang tua dapat mengawasi dan dapat mengetahui segala kekurangan dan kesulitan anak dalam belajarnya. Bimbingan dari orang tua dapat juga berperan sebagai cara untuk peningkatan disiplin terutama dalam belajarnya.

Dari pendapat ini seorang anak apabila mempunyai motivasi yang kuat dalam belajarnya akan dapat meningkatkan prestasi belajarnya, akan tetapi tidak semua anak bisa mempunyai molivasi ini, banyak anak yang menjadi siswa yang dalam proses belajar kurang atau tidak mempunyai motivasi, maka diperlukan bimbingan belajar dari orang tuanya.

\section{Pengertian Orang Tua dan Tanggung Jawabnya Terhadap Anak}

Dalam Kamus Besar Bahasa Indonesia (1996:706) kata orang tua adalah ayah, ibu kandung, duan orang yang diangap tua. Sedangkan Kartono (1998:2) orang tua adalah bapak/ibu yang memiliki wewenang dan tanggung jawab untuk membesarkan anak-anaknya.

Dari kedua pendapat tersebut maka yang dimaksud dengan orang tua adalah ayah ibu kandung yang memiliki wewenang dan tanggungjawab untuk membesarkan anak-anaknya. Dengan demikian maka yang dimaksud dengan istilah Bimbingan orang tua adalah perihal Bimbingan atau cara yang dilakukan oleh orang tua (ayah dan ibu) yang memiliki wewenang dan tanggung jawab untuk membesarkan anakanaknya.

Berdasarkan kedua pendapat di atas yang dimaksud dengan bimbingan adalah suatu proses pemberian bantuan yang terus menerus dan sistematis kepada individu dalam memecahkan masalah yang dihadapi agar tercapai kemampuan untuk dapat memahami diriya (Self Understanding), kemampuan untuk mengarahkan dirinya (Self Direction), kemampuan untuk menerima dirinya (Self Acceptance), sesuai dengan potensi atau kemampuan dalam mencapai penyesuaian diri dengan lingkungan, baik keluarga, sekolah, maupun masyarakat dan bantuan itu diberikan oleh orang-orang yang memiliki keahlian dan pengalaman khusus dalam bidang tersebut. 


\section{Metodelogi Penelitian}

\section{Hipotesis Penelitian}

Hipotesis merupakan jawaban sementara terhadap rumusan masalah penelitian, dimana rumusan masalah penelitian telah dinyatakan dalam bentuk kalimat pertanyaan. Sedangkan menurut Nasution dalam bukunya yang berjudul Metode Research mengatakan hipotesis adalah pernyataan tentatif yang merupakan dugaan atau terkaan tentang apa saja yang kita amati dalam usaha untuk memahaminya.

Berdasarkan uraian di atas maka hipotesis dalam penelitian ini adalah sebagai berikut: komunikasi guru dengan siswa terhadap bimbingan orang tua efektif dalam meningkatkan prestasi belajar siswa pada bidang studi IPS terpadu kelas XI Madrasah Aliyah Assa'adah Labuapi Kabupaten Lombok Barat.

\section{Desain Penelitian}

Desain penelitian merupakan rencana tentang cara mengumpulkan dan menganalisis data agar dapat dilaksanakan secara IPS terpadu serta serasi dengan tujuan penelitian itu. Dalam penelitian ini, penelitian yang digunakan adalah penelitian kuantitatif yang meneliti tentang pengaruh komunikasi guru-siswa dan bimbingan orang tua terhadap prestasi belajar siswa kelas IX di Madrasah Aliyah Assa'adah Labuapi Lombok Barat dengan menggunakan pendekatan kuantitatif. Maka dalam penelitian banyak dituntut menggunakan angka, mulai dari pengumpulan data, penafsiran terhadap data tersebut serta penampilan dari hasilnya. Penelitian ini menggunakan pendekatan kuantitatif dimana peneliti ingin meneliti komunikasi gurusiswa dan bimbingan orang tua yang berpengaruh terhadap prestasi belajar siswa, artinya bahwa data-data yang diperoleh di lapangan dikerjakan melalui proses menghimpun, menyusun, mengatur, mengolah, menyajikan dan menganalisa dengan analisis statistik, sehingga melalui proses tersebut dapat ditarik kesimpulan atas datadata yang ada.

\section{Data dan Sumber Data}


Data merupakan sejumlah fakta atau keterangan yang digunakan sebagai sumber atau bahan. Sumber data yang digunakan pada penelitian ini dapat dilihat pada tabel berikut:

Tabel 01 : Data dan Sumber Data

\begin{tabular}{|l|l|l|}
\hline \multicolumn{1}{|c|}{ Data } & \multicolumn{1}{|c|}{ Sumber data } & \multicolumn{1}{c|}{ Instrumen } \\
\hline $\begin{array}{l}\text { Komunikasi Guru dengan } \\
\text { murid }\end{array}$ & $\begin{array}{l}\text { Tindakan guru selama proses } \\
\text { pembelajaran berlangsung }\end{array}$ & $\begin{array}{l}\text { Lembar observasi kegiatan } \\
\text { guru }\end{array}$ \\
\hline Bimbingan Orang Tua & Aspek kognitif siswa & Soal tes \\
\hline Prestasi Belajar Siswa & Sikap kemandirian & Angket \\
\hline
\end{tabular}

\section{Metode Pengumpulan Data}

\section{Metode Wawancara}

Wawancara digunakan untuk mengetahui kondisi siswa sebelum penelitian dilakukan. Informan dalam wawancara adalah guru Madrasah Aliyah Assa'adah Labuapi Lombok Barat Tahun Pelajaran 2016-2017.

\section{Metode Observasi}

Observasi yang dilakukan adalah observasi langsung. Observasi dilakukan dengan menggunakan lembar observasi. Pada penelitian ini lembar observasi yang digunakan adalah lembar observasi kegiatan guru.

\section{Metode Dokumentasi}

Metode dokumentasi adalah suatu cara untuk mencari data atau hal-hal yang berupa catatan trankrip, agenda dan sebagainya.

\section{Metode Angket}

Angket adalah suatu daftar yang berisi pertanyaan-pertanyaan yang harus dijawab atau dikerjakan oleh orang-orang yang menjadi sasaran angket tersebut. Secara rinci prosedur dan tahap-tahap pada penelitian ini akan diuraikan sebagai berikut:

\section{Siklus I}

a. Rencana Tindakan (Planning)

Tahap 1 Orientasi siswa pada masalah 
Tahap 2 mengorganisasi siswa untuk belajar

Tahap 3 membimbing penyelidikan individual dan kelompok

Tahap 4 mengembangkan dan menyajikan hasil karya

b. Observasi

Dalam melakukan tindakan guru juga melakukan observasi terhadap kemampuan berpikir siswa dan data lain yang berkaitan dengan tindakan yang diberikan sehingga diperoleh data penelitian.

c. Refleksi

Dari hasil pengamatan terhadap proses pembelajaran dan hasil belajar siswa akan diperoleh informasi tentang kelebihan dan kekurangan siklus I. Hasil data dari siklus I direfleksikan dan digunakan sebagai pedoman untuk menyusun tindakan pada siklus selanjutnya.

\section{Siklus II}

Setelah merefleksikan siklus I maka pada siklus II ini pada hakekatnya adalah melengkapi kekurangan dan yang perlu diperbaiki pada siklus I guna menghasilkan hasil akhir atau kesimpulan penelitian. Adapun tahapan siklus II ini adalah sebagai berikut:

a. Rencana Tindakan (Planning)

Menyusun rencana pembelajaran siklus II

Menyiapkan instrumen penelitian berupa lembar observasi kegiatan guru, tes kemampuan berpikir kritis siklus II.

Menyiapkan Lembar Kerja Siswa (LKS) siklus II.

b. Pelaksanaan Tindakan (Action)

Tahap 1 orientasi siswa pada masalah

Tahap 2 mengorganisasi siswa untuk belajar

Tahap 3 membimbing penyelidikan individual dan kelompok

Tahap 4 mengembangkan dan menyajikan hasil karya

Tahap 5 menganalisis dan mengevaluasi proses pemecahan masalah.

c. Observasi

Dalam melakukan tindakan, guru juga melakukan observasi terhadap kemampuan berpikir siswa dan data lain yang berkaitan dengan tindakan yang diberikan sehingga diperoleh data penelitian. 


\section{d. Refleksi}

Data yang diperoleh dari hasil pengamatan dan hasil belajar siswa tersebut dianalisis dan dibahas. Pada akhir siklus ini akan diperoleh gambaran tentang motivasi dan hasil belajar siswa setelah menerapkan pembelajaran berbasis masalah. Hasil pembahasan merupakan refleksi dari apa yang telah terjadi selama penerapan tindakan.

\section{Teknik Analisis Data}

Analisis merupakan bagian yang amat penting dalam metode ilmiah karena dengan analisis data tersebut dapat diberi arti dan makna yang berguna dalam memecahkan masalah penelitian, secara garis besar pekerjaan menganalisis data meliputi tiga langkah yaitu:

Persiapan

Kegiatan peneliti dalam rangka persiapan antara lain.

a. Mengecek nama dan kelengkapan identitas pengisi. dalam hal ini peneliti akan mengecek kembali identitas terwawancara, observer, dan mengisi angket yang telah disebarkan.

b. Mengecek kelengkapan data, artinya peneliti memeriksa kembali instrumen pengumpulan data dan termasuk kelengkapan lembaran instrumen.

c. Mengecek macam isian data maksudnya apabila dalam instrumen terdapat sesuatu atau beberapa item-item yang diisi tidak tahu, padahal isian tersebut merupakan variabel pokok dalam item, maka item tersebut harus didrop atau dihilangkan.

1. Tabulasi

Tabulasi dapat dilakukan jika semua masalah yang berhubungan dengan persiapan sudah terselesaikan.

2. Penerapan data sesuai denagan pendekatan penelitian.

Pendekatan penelitian yang peneliti gunakan adalah pendekatan kuantitatif. Dalam penerapan data atau menganalisa data peneliti menggunakan rumus korelasi product moment.

Data penerapan langkah-langkah pembelajaran berbasis masalah dianalisis secara deskriptif berdasarkan ketercapaian tindakan yang dilakukan oleh guru. Hal ini 
ditunjukkan dengan banyaknya tanda cek $(\sqrt{ })$ pada kolom "ya" dilembar observasi presentasi ketercapaian tindakan guru dengan rumus:

Presentase ketercapaian tindakan guru.

$=$ Jumlah Tanda $(\sqrt{ })$ pada kolom "ya" x 100

Jumlah total tanda $(\sqrt{ })$

Ketercapaian tindakan guru pada siklus I diukur dari presentase yang dicapai guru pada siklus I. Tindakan dikatakan tercapai jika persentase telah mencapai $\geq 75 \%$ (Mulyasa, 2003). Sedangkan ketercapaian tindakan guru pada siklus II ditentukan berdasarkan refleksi siklus I. Dari sini dapat terlihat apakah terjadi peningkatan antara siklus I dan siklus II. Data kemampuan berpikir kritis dianalisis secara deskriptif berdasarkan presentase ketercapaian kemampuan berpikir kritis sesuai rubrik penilaian kemapuan berpikir kritis dengan rumus:

$$
P=\frac{F}{N} x 100 \%
$$

Keterangan:

$\mathrm{P}=$ Persentase Tingkat Komunikasi Guru dengan Murid

$\mathrm{F}=$ Jumlah Nilai Tingkat Bimbingan Orang Tua

$\mathrm{N}=$ Jumlah Nilai Tingkat Prestasi Belajar Siswa

Sebagai pedoman dalam mengambil keputusan/kesimpulan dari hasil analisis data dengan menggunakan persentase ditetapkan klasifikasi yang juga mengacu pada pendapat Arikunto Suharsismi (2002) sebagai berikut:

Tabel 02 : Kriteria Persentase Komunikasi Guru dengan Murid

\begin{tabular}{|c|c|c|}
\hline No. & Prosentase & Klasifikasi \\
\hline 1. & $92 \%-100 \%$ & Baik Sekali \\
\hline 2. & $75 \%-91 \%$ & Baik \\
\hline 3. & $50 \%-74 \%$ & Cukup Baik \\
\hline 4. & $25 \%-49 \%$ & Kurang Baik \\
\hline 5. & $0 \%-24 \%$ & Tidak Baik \\
\hline
\end{tabular}

Sumber: Arikunto (2002) 
Data kemandirian belajar dianalisis secara deskriptif berdasarkan hasil angket yang telah disebarkan kepada siswa. Setiap jawaban a diberi nilai 4, jawaban b diberi nilai 3, jawaban c diberi nilai 2 dan jawaban d diberi nilai 1.

Dengan demikian nilai terendah yang mungkin dicapai adalah $1 \times 25=25$ dan nilai tertinggi 4x25=100. Tingkat kemandirian dalam belajar dibagi menjadi empat kategori dengan cara membagi selisih nilai terendah dan nilai tertinggi sehingga tingkatan kemandirian belajar dibagi sebagai berikut:

\section{Tabel 03: Kriteria Prestasi Belajar}

\begin{tabular}{|c|c|c|}
\hline No. & Skor & Kriteria \\
\hline 1. & $82-100$ & Sangat tinggi \\
\hline 2. & $63-81$ & Tinggi \\
\hline 3. & $44-62$ & Kurang tinggi \\
\hline 4. & $25-43$ & Rendah \\
\hline
\end{tabular}

\section{Kegiatan Pra Tindakan}

\section{Observasi Awal}

Pada tahap ini peneliti telah melakukan observasi awal ke Madrasah Aliyah Assa'adah Labuapi Kabupaten Lombok Barat Provinsi Nusa Tenggara Barat sebanyak dua kali. Dari hasil wawancara secara informal dengan guru IPS terpadu Madrasah Aliyah Assa'adah Labuapi Lombok Barat diketahui bahwa kemandirian belajar siswa masih rendah, siswa masih terlihat kesulitan untuk mengaitkan materi yang diperoleh di sekolah dengan masalah yang ada di sekitar mereka. Selain itu dalam mengerjakan tugas yang diberikan guru kebanyakan siswa masih bersifat teksbook mereka masih terpacu pada buku, hanya sebagian siswa yang menggunakan kemampuan bernalar mereka untuk menanggapi permasalahan yang disajikan.

Dalam hal kemandirian belajar siswa masih menunggu guru datang ke kelas daripada berinisiatif untuk belajar sendiri, selama guru belum hadir jarang siswa yang berdiskusi dengan teman tentang materi yang akan diajarkan atau materi yang telah lalu, kebanyakan dari mereka ramai dan hanya bercanda. Adapun sumber belajar yang dimiliki siswa hanya terbatas pada buku paket yang ada di perpustakaan dan LKS.

\section{Refleksi Awal}


Berdasarkan hasil observasi awal dan wawancara informal dengan guru Madrasah Aliyah Assa'adah Labuapi Lombok Barat diketahui bahwa kemandirian belajar siswa masih kurang. Hal ini perlu ditindaklanjuti dengan tindakan untuk meningkatkan kualitas pembelajaran. Tindakan yang dipilih adalah penerapan pembelajaran berbasis masalah dengan harapan dapat meningkatkan kemampuan kemandirian belajar siswa.

\section{Jalannya Pembelajaran Pada Siklus I}

\section{Perencanaan Tindakan}

Berdasarkan hasil analisis dan refleksi awal maka peneliti dan guru IPS terpadu Madrasah Aliyah Assa'adah Labuapi Lombok Barat merencanakan tindakan perbaikan untuk memperbaiki kualitas proses belajar mengajar. Peneliti bersama guru IPS terpadu merancang rencana pembelajaran, lembar kerja siswa siklus I, lembar observasi kegiatan guru, angket kemandirian belajar siswa. Kelompok dalam pembelajaran ini terdiri dari 6 kelompok yang pengelompokannya didasarkan pada nilai siswa semester gasal dan keakraban yang sudah terjalin diantara siswa. Hal ini dilakukan agar siswa lebih nyaman sehingga dapat bekerjasama dengan baik dalam kelompok.

\section{Tindakan}

Siklus I dilaksanakan selama satu kali pertemuan peneliti bertindak sebagai guru ditemani dengan dua observer yang semuanya adalah siswa Madrasah Aliyah Assa'adah Labuapi Lombok Barat. Pembelajaran pada siklus I berlangsung selama 90 menit yaitu pada pukul 07.30 sampai dengan pukul 9.00 yang diikuti oleh 40 orang siswa. Guru mengawali pembelajaran dengan mengucapkan salam dan doa bersama, kemudian menjelaskan tujuan pembelajaran.

Langkah pembelajaran yang dilakukan oleh guru sesuai dengan langkahlangkah pembelajaran berbasis masalah. Dalam hal ini guru membantu siswa menyusun laporan diskusi kelompok, pada sesi ini siswa menyelesaikan tugas kelompok melebihi batas waktu yang telah ditentukan. Tahap kelima adalah menganalisis dan mengevaluasi proses pemecahan masalah, pada tahap ini guru bersama-sama siswa mengevaluasi hasil diskusi kelompok melalui presentasi kelompok, kelompok yang presentasi adalah kelompok 6 namun pada saat berlangsungnya kelompok 6 mempresentasikan hasil diskusi kelompoknya, kelompok 
yang lain tidak memperhatikan, mereka sibuk menyelesaikan tugas kelompok masingmasing sehingga diskusi kelas tidak berjalan dengan baik. Sebelum pembelajaran selesai waktu sudah habis sehingga guru belum sempat memberikan refleksi dan kesimpulan pembelajaran yang telah dilakukan.

\section{Temuan Penelitian}

\section{Komunikasi Guru dengan Murid}

Kemampuan siswa diukur melalui tes uraian yang diberikan di akhir pembelajaran. Penilaian masing-masing skor soal memiliki rentangan skor 0 - 4 . Kemampun merumuskan masalah, melakukan deduksi berdasarkan artikel tentang biaya produksi yang disajikan, memberikan argumen, dan melakukan evaluasi dengan mengajukan alternatif penyelesaian terhadap masalah yang disajikan.

\section{Bimbingan Orang Tua}

Kemandirian belajar siswa diukur melalui angket kemandirian belajar yang diberikan pada akhir pembelajaran siklus I. Berdasarkan data hasil angket komunikasi guru dengan siswa pada siklus I diketahui skor terendah yang diperoleh siswa adalah 50 dan skor tertinggi 79 seperti disajikan dalam tabel berikut:

Tabel 04 : Klasifikasi Bimbingan Orang Tua Siklus I

\begin{tabular}{|c|c|c|c|}
\hline Rentangan Skor & Klasifikasi & $\begin{array}{c}\text { Jumlah } \\
\text { siswa }\end{array}$ & Persentase \\
\hline $82-100$ & Sangat tinggi & - & - \\
\hline $63-81$ & Tinggi & 27 orang & $67,5 \%$ \\
\hline $44-62$ & Kurang tinggi & 13 orang & $32,5 \%$ \\
\hline $25-43$ & Rendah & - & - \\
\hline
\end{tabular}

Sumber: data hasil penelitian kemandirian belajar siswa

Berdasarkan tabel di atas kemandirian belajar siswa sudah tinggi yaitu 67,5\% dan 32,5\% siswa memiliki kemandirian belajar kurang tinggi. Siswa yang memperoleh skor 44-62 sebanyak 13 orang dan siswa yang memperoleh skor 63-81 sebanyak 27 orang sehingga diperoleh rata-rata skor 65,62.

\section{Hasil Observasi Langkah PBM Yang Dilakukan Guru}

Data hasil observasi terhadap pembelajaran yang diterapkan oleh guru meliputi observasi langkah-langkah PBM yang dilakukan guru pada sub pokok 
bahasan biaya produksi. Berdasarkan hasil data observasi penerapan pembelajaran yang dilakukan guru pada siklus I diketahui bahwa guru telah melakukan deskriptor pembelajaran berbasis masalah namun guru belum menjelaskan pembelajaran berbasis masalah kepada siswa sehingga ada sebagian siswa yang masih menanyakan maksud dari pembelajaran berbasis masalah, guru kurang memberdayakan pertanyaan provokatif untuk meningkatkan keterampilan bertanya tingkat tinggi dan belum melakukan refleksi terhadap proses pembelajaran yang telah dilakukan karena keterbatasan waktu. Ketercapaian tindakan guru pada siklus I adalah 70\%.

\section{Refleksi siklus I}

Berdasarkan hasil ketercapaian kegiatan pembelajaran pada siklus I maka peneliti bersama dengan observer kegiatan melakukan refleksi tentang pembelajaran yang telah dilakukan. Refleksi ini dilakukan sebagai bahan pertimbangan dan perbaikan pada siklus berikutnya. Ada beberapa catatan penting pada siklus I sebagai berikut:

a. Guru belum melakukan semua tindakan pada pembelajaran berbasis masalah. Hal ini ditunjukkan oleh persentase ketercapaian tindakan guru sebesar 70\%. Pada siklus I guru belum memberdayakan pertanyaan provokatif untuk memancing kemampuan berpikir tingkat tinggi siswa dan belum melakukan refleksi/menyimpulkan materi karena keterbatasan waktu.

b. Penggunaan waktu yang kurang efisien. Waktu pembelajaran tidak sesuai dengan yang direncanakan, waktu banyak terbuang pada saat peneliti membagi siswa dalam kelompok.

c. Peneliti kurang tegas dalam menentukan waktu kerja kelompok sehingga siswa mengerjakan tugas yang diberikan melewati batas waktu yang telah ditentukan.

d. Sebagai moderator guru kurang bisa membimbing kegiatan diskusi. Hal ini dapat diketahui pada waktu kelompok 6 mempresentasikan hasil kerjanya di depan kelas, kelompok yang lain tidak memperhatikan, mereka masih sibuk menyelesaikan tugas kelompoknya sendiri sehingga suasana kelas menjadi gaduh, hal ini juga dipengaruhi oleh waktu pembelajaran yang singkat.

Untuk memperbaiki pembelajaran berikutnya guru harus lebih tegas memberikan instruksi tugas pada siswa terutama masalah waktu, selain itu guru harus bisa mengelola dan mengatur siswa untuk lebih tertib dan memperhatikan kelompok 
yang presentasi sehingga semua siswa bisa lebih aktif dan memahami materi. Berdasarkan refleksi siklus I ada beberapa kelebihan dalam pembelajaran berbasis masalah yang diterapkan guru pada kelas IX ini, antara lain sebagian besar siswa kelas IX sudah bisa bekerjasama dengan baik dan terlibat aktif memecahkan masalah dalam kelompoknya, lembar kerja siswa (LKS) yang disajikan oleh guru membantu siswa berpikir dan mandiri dalam mencari konsep materi yang sedang dipelajari.

\section{Jalannya Pembelajaran Pada Siklus II}

\section{Perencanaan Tindakan}

Berdasarkan refleksi guru Bidang Studi IPS terpadu dan 2 orang observer pada siklus I, maka peneliti merencanakan tindakan perbaikan. Adapun tindakan yang direncanakan adalah memberikan instruksi yang tegas tentang tugas dan tanggung jawab siswa terutama masalah waktu dan mengatur jalannya diskusi.

\section{Tindakan}

Tindakan pada siklus II dilakukan dalam 2 kali pertemuan, yaitu pertemuan pertama dilakukan pada tanggal 2 Pebruari 2013 pada pukul 07.30 sampai dengan pukul 08.40. Pada saat masuk kelas guru menyapa siswa, mengucapkan salam, dan mengecek kelengkapan siswa, pada pertemuan pertama ini ada seorang siswi yang tidak hadir. Pada awal pembelajaran siswa belum konsentrasi pada materi yang akan disampaikan, ada beberapa siswa yang masih bingung mencari tempat duduk karena kelas ini baru dipakai ujian nasional, untuk mengatasi hal ini guru meminta bantuan pada salah satu siswa laki-laki untuk mengambilkan tempat duduk untuk temannya.

Tahap kedua adalah mengorganisasi siswa untuk belajar. Setelah semua siswa fokus pada materi, guru mulai menginstruksikan siswa untuk berkumpul dengan kelompoknya dan membagikan lembar kerja kelompok yang telah disiapkan. Tahap ketiga membimbing penyelidikan individual. Pada sesi ini siswa terlihat aktif melakukan diskusi dengan kelompoknya membahas permasalahan yang ada pada artikel LKS, siswa sudah mulai berinisiatif membagi tugas dengan anggota kelompoknya sehingga semua anggota dalam kelompok aktif mengerjakan tugas masing-masing. Di sela-sela kegiatan diskusi ada beberapa kelompok yang masih belum mengerti tentang tugasnya sehingga menanyakan pada guru, untuk menanggapi hal ini maka guru memberikan pengarahan dan bimbingan dengan berkeliling dari satu kelompok ke kelompok yang lain. 
Tahap pertama diawali guru dengan mengucapkan salam dan menanyakan tugas pengamatan kelompok, kemudian guru mengorganisasi untuk belajar yaitu memotivasi siswa. Setelah siswa mulai konsentrasi pada materi, guru memulai pembelajaran yaitu dengan mengintstruksikan kepada siswa untuk berkumpul dengan kelompoknya masing-masing.

Tahap kedua adalah membimbing penyelidikan individual maupun kelompok, dalam hal ini guru memberi tugas kelompok kepada siswa untuk mengunjungi salah satu kelompok yang ada disekitar tempat tinggal, instruksi ini sudah dilakukan pada akhir pembelajaran pertemuan sebelumnya sehingga siswa sudah siap dengan laporan pengamatan. Pada tahap ini guru menugaskan siswa untuk membuat laporan pengamatan yang kemudian dipresentasikan di depan kelas.

\section{Temuan Penelitian}

\section{Komunikasi Guru dengan Murid}

Berdasarkan data hasil kemampuan siswa berkomunikasi dengan guru pada siklus II dapat diketahui siswa memperoleh skor terendah 64,28 dan skor tertinggi 96,42 sehingga diperoleh rata-rata skor 80,98.

\section{Bimbingan Orang Tua}

Penilaian kemandirian belajar siswa pada siklus II sama seperti halnya pada siklus I yaitu diukur melalui angket kemandirian belajar pada akhir siklus. Berdasarkan data hasil angket kemandirian belajar diperoleh skor terendah 55 dan skor tertinggi 84. Adapun klasifikasi prestasi belajar siswa kelas X dapat dilihat pada tabel berikut:

\section{Tabel 05 : Klasisifikasi Prestasi Belajar Siswa Siklus II}

\begin{tabular}{|c|c|c|c|}
\hline Rentangan Skor & Klasifikasi & Jumlah siswa & Persentase \\
\hline $82-100$ & Sangat tinggi & 2 orang & $5 \%$ \\
\hline $63-81$ & Tinggi & 29 orang & $72,5 \%$ \\
\hline $44-62$ & Kurang tinggi & 9 orang & $22,5 \%$ \\
\hline $25-43$ & Rendah & - & - \\
\hline
\end{tabular}

Sumber: data hasil penelitian kemandirian belajar siswa

Berdasarkan tabel di atas dapat disimpulkan bahwa prestasi belajar siswa kelas IX lebih tinggi dari siklus I. Hal ini dibuktikan ada 5\% siswa yang sudah memiliki 
prestasi belajar sangat tinggi, 72,5\% siswa yang dapat berkomunikasi dengan gurunya sangat tinggi dan sebesar 22,5\% siswa memiliki prestasi belajar kurang tinggi. Siswa yang memperoleh skor 44-62 sebanyak 9 orang, siswa yang memperoleh skor 63-81 sebanyak 29 orang, dan siswa yang memperoleh skor 82-100 sebanyak 2 orang sehingga diperoleh rerata skor 67,45.

\section{Refleksi Siklus II}

Berdasarkan observasi dan hasil evaluasi pembelajaran pada siklus II dapat diuraikan sebagai berikut:

a. Sebelum melaksanakan pembelajaran pada siklus II, peneliti sudah melakukan diskusi dengan guru dua orang observer mengenai rencana pembelajaran yang dibuat guru serta mengenai tugas-tugas yang diberikan kepada siswa agar tujuan pembelajaran dapat tercapai dan guru sepakat bahwa pada siklus II siswa akan melakukan pengamatan ke kelompok lain.

b. Setelah melakukan kegiatan pembelajaran pada siklus II ini, peneliti sebagai observer melakukan refleksi bahwa pada siklus II guru telah melakukan semua tindakan pembelajaran sehingga persentase ketercapaian tindakan guru mencapai $100 \%$.

\section{Pembahasan}

\section{Prestasi Belajar Siswa}

Berdasarkan data hasil pada siklus dan siklus II diketahui bahwa rata-rata skor kelas pada siklus I sebesar 62,5 dan siklus II sebesar 80,98, sehingga ada peningkatan sebesar 18,48. Peningkatan yang cukup pesat ini di sebabkan karena sebelum memasuki siklus II siswa sudah memiliki pengalaman dan kemampuan awal yang diperoleh pada siklus I, selain itu siswa sudah melakukan pengamatan langsung pada kelompok yang ada di sekitar tempat tinggal siswa dan mulai belajar mengkaji hasil kerja kelompok tersebut sehingga tingkat kemandirian belajar siswa semakin tinggi.

Berdasarkan hasil skor angket kemandirian belajar siswa kelas IX pada siklus I kemandirian belajar siswa kelas IX sudah tiggi yaitu 67,5\% dan 32,5\% siswa memiliki kemandirian belajar kurang tinggi. Siswa yang memperoleh skor 44-62 sebanyak 13 orang dan siswa yang memperoleh skor 63-81 sebanyak 27 orang sehingga secara klasikal diperoleh rerata skor 65,62. Berdasarkan data tersebut siswa kelas IX dapat dikategorikan pada kemandirian belajar tinggi. 
Pada siklus II diperoleh data bahwa ada 5\% siswa yang sudah memiliki kemandirian belajar sangat tinggi, 72,5\% siswa dengan kemandirian tinggi dan sebesar $22,5 \%$ siswa memiliki kemandirian belajar kurang tinggi. Siswa yang memperoleh skor 44-62 sebanyak 9 orang, siswa yang memperoleh skor 63-81 sebanyak 29 orang, dan siswa yang memperoleh skor 82-100 sebanyak 2 orang sehingga diperoleh rerata skor 67,45 .

Dari data tersebut berarti ada peningkatan kemandirian belajar siswa sebesar 1,82. Peningkatan skor kemandirian belajar siswa kelas IX sangat kecil, hal ini sangat dipengaruhi oleh situasi dan kondisi siswa pada saat mengisi angket kemandirian belajar yang disediakan guru siswa sudah mulai bosan mangisi angket sehingga dalam mengisi terkadang sembarangan.

\section{Prestasi Belajar IPS terpadu}

Pengajaran berbasis masalah merupakan suatu pendekatan pengajaran yang menggunakan masalah dunia nyata sebagai suatu konteks bagi siswa untuk belajar tentang cara berpikir kritis dan keterampilan pemecahan masalah, serta untuk memperoleh pengetahuan dan konsep yang esensial dari materi pelajaran. Berdasarkan hasil observasi pembelajaran berbasis masalah pada siklus I, diperoleh persentase keberhasilan pembelajaran sebesar $70 \%$.

Pada pembelajaran tersebut guru belum memberdayakan pertanyaan provokatif untuk memancing kemampuan berpikir tingkat tinggi siswa, selain itu guru belum melakukan refleksi dan menyimpulkan tentang pembelajaran yang telah dilakukan. Hal ini dipengaruhi oleh terbatasnya waktu pembelajaran yang hanya berlangsung selama 60 menit. Sebagian besar siswa tidak bisa menyelesaikan permasalahan yang disajikan oleh guru. Berdasarkan refleksi tindakan pembelajaran bersama guru dan dua orang observer, guru dapat meningkatkan persentase pencapaian pembelajaran pada siklus berikutnya, guru sudah melakukan semua indiokator pembelajaran berbasis masalah sehingga persentase pencapaian hasil sebesar 100\%. Dari hasil tersebut dapat diketahui adanya peningkatan sebesar 30\%.

Pada siklus I sebagian besar kelompok belum bisa menyelesaikan pekerjaannya sesuai waktu yang telah ditentukan. Mereka masih kesulitan dalam merumuskan masalah dan mencari solusi pemecahan masalah, hal ini juga dipengaruhi oleh tanggung jawab masing-masing anggota kelompok. Mereka tidak 
memiliki inisiatif untuk membagi tugas dan menyelesaikan tugas sesuai dengan bagiannya, untuk mengatasi masalah ini guru membimbing siswa untuk memahami artikel dan membagi tugas dalam kelompok.

Pada siklus II siswa sudah bisa menyelesaikan permalahan yang disajikan sesuai dengan waktu yang telah ditentukan, siswa sudah mulai terbiasa dalam merumuskan masalah dan mulai sadar akan tugas dan tanggungjawabnya dalam kelompok. Pada akhir siklus II guru melatih siswa untuk belajar dengan menggunakan media lingkungan sekitar yaitu mengunjungi perusahaan-perusahaan yang ada disekitar tempat tinggal. Hal ini dilakukan agar siswa belajar tidak hanya terpaku pada materi yang ada dibuku tetapi melalui media pembelajaran yang lain dan ada disekitarnya yang dapat meningkatkan pengetahuannya sehingga konsep yang diperoleh lebih bermakna bagi siswa.

Siswa diberi kebebasan untuk memilih dan menentukan tempat usaha yanng akan mereka kunjungi sesuai dengan kondisi lingkungan mereka, mencari permasalahan yang ada diperusahaan yang mereka kunjungi untuk dicarikan penyelesaian dan didiskusikan dengan anggota kelompoknya. Kondisi ini akan mendorong motivasi belajar siswa karena mereka benar-benar terlibat langsung dan mengalami sendiri kegiatan yang mereka lakukan sehingga konsep yang mereka dapatkan lebih melekat dan lebih bermakna bagi siswa itu sendiri.

Berdasarkan hasil wawancara dengan guru bidang studi IPS terpadu kelas IX pembelajaran berbasis masalah mempunyai kelebihan sebagai berikut:

a. Pembelajaran berbasis masalah membuat siswa lebih kreatif dalam menggali materi.

b. Pembelajaran berbasis masalah dapat menimbulkan ide-ide baru karena siswa tidak hanya belajar dari buku.

c. Pembelajaran berbasis masalah menjadikan siswa lebih mandiri dalam belajar karena siswa dituntut untuk menggali materi dari permasalahan yang disajikan.

d. Pembelajaran berbasis masalah dapat meningkatkan keakraban dan kerjasama antar sesama siswa karena bekerja dalam kelompok. Sedangkan kelemahan pembelajaran berbasis masalah adalah sebagai berikut:

1. Bagi siswa yang tidak suka membaca tidak akan memperoleh konsep yang ada pada masalah yang disajikan sehingga pembelajaran menjadi tidak bermakna. 
2. Pembelajaran berbasis masalah biasanya dilakukan dalam kelompok sehingga memungkinkan siswa yang malas menjadi semakin malas karena hanya bergantung pada kelompoknya.

3. Siswa merasa guru tidak pernah menerangkan karena dalam pembelajaran berbasis masalah menuntut siswa untuk mandiri dalam memahami pembelajaran sehingga siswa kadang-kadang menjadi bosan.

\section{Catatan Akhir}

Berdasarkan hasil penelitian pada proses belajar mengajar IPS terpadu pada kelas IX pada bidang studi IPS terpadu Madrasah Aliyah Assa'adah Labuapi Lombok Barat, maka dapat diambil kesimpulan sebagi berikut:

1. Penerapan model pembelajaran berbasis masalah pada bidang studi IPS terpadu dapat meningkatkan kemampuan belajar siswa kelas XI MA. Assa'adah Labuapi Lombok Barat. Hal ini dapat dilihat dari peningkatan skor kemampuan belajar siswa pada siklus I dan siklus II.

2. Model pembelajaran berbasis masalah pada bidang studi IPS terpadu dapat meningkatkan kemandirian belajar siswa kelas XI MA. Assa'adah Labuapi Lombok Barat. Hal ini dibuktikan dari peningkatan skor kemandirian belajar siklus I dan II.

3. Penerapan model pembelajaran berbasis masalah dapat meningkatkan kemandirian belajar siswa kelas XI MA. Assa'adah Labuapi Lombok Barat Tahun Pelajaran 2016-2017.

\section{Daftar Rujukan}

Anakciremai, Makalab Psikologi tentang bimbingan orang tua dalam membina akblak anak usia pra sekolah di lingkungan keluarga, dalam www.anakciremai.com/...../makalah-psikologi-tentang bimbingan.htm. Diakses pada tanggal 2 Juni 2016.

Djamarah, Prestasi Belajar Dan Kompetensi Guru, Surabaya, Usaha Nasional: 1994.

Hamalik, 2001. Kurikulum Dan Pembelajaran, Bandung: Sinar Baru.

Heru, Teori tentang bimbingan orang tua, dalam heru-id.blogspot. com/.../teori-tentangbimbingan-orang-tua.htm._DiAksespada tanggal 03 Februari 2010 
Rahmawati

Ibnu Subiyanto, 2000. Metodelogi penelitian manajemen dan akuntansi, Yogyakarta: UPP AMP YKPN.

Nasution, 2004. Metode Research, Jakarta: Bumi Aksara.

Nana Sudjana, 2009. Dasar-dasar Proses Belajar Mengajar, Bandung: Sinar Baru Algensindo.

Sudjana, CBSA 1996. (Surabaya: Sinar Baru Aigesindo).

Sugiono, 2007. Metode Penelitian Pendidikan, Bandung: Alfabeta.

Suharsimi Arikunto, 2006. Prosedur Penelitian Suatu Pendekatan Praktik, Jakarta: Rineka Cipta.

Usman, dkk. 2001. Upaya Optimalisasi Belajar Mengajar, Bandung: PT. Remaja Rosdakrya.

Poerwadarminto, 1994. Ilmu Pendidikan Teoritis dan Praktis, Bandung, PT. Remaja Rosdakarya.

Roestiyah, 1991. Strategi Belajar Mengajar, Jakarta: Rineka Cipta. 